\title{
Research on theImpact of Financial Policies on the Development of New Energy Vehicles
}

\author{
Xia Huadan \\ School of Mechatronics Engineering, Wuhan business University, Wuhan 430056, China \\ crystal-bb@qq.com
}

Keywords: Impact, Financial Policies, Development, New Energy Vehicles

\begin{abstract}
The government's intervention in industrial development permeates all stages of economic development. In the current period of economic restructuring, the government continues to support and guide the development of some industries. In the new economic normal, the new energy automotive industry is not only an important source of innovation-driven development, but also is related to the wild for the sustainable development of green environmental protection needs. According to the actual situation of the new energy automotive industry and its development in the process, if people only rely on the market mechanism, the development of the new energy automotive industry will be constrained by many factors such as technology and capital to break the initial plight of industrial development. Therefore, in the early stage of the development of new energy automotive industry, it is necessary to support the government subsidies, encourage innovation and other policies, improve the industrial chain and attract social capital so as to promote the expansion of new energy automotive industry and technological progress.
\end{abstract}

\section{Introduction}

Automobile industry is an important pillar industry in our country's national economy and social development. In recent years, Chinese automobile sales and possession have been developing rapidly with the rapid economic development and urbanization. It has become the world's automobile production and sales volume in order to develop China into a new power automobile, it is necessary to develop a new energy automobile. At the same time, all countries in the world will also promote the development of the new energy automobile industry to the strategic level of national development. Since the beginning of promotion to 2013, the new energy automotive industry has always been in a "noisy" position. Due to the market failure caused by the characteristics and development of the new energy automobile industry, all countries in the world, especially the relatively developed countries, are trying to accelerate the development of new energy vehicles Industrial into the implementation phase of production has promulgated a series of industrial policies to guide and support the new energy automotive industry healthy and rapid development. With the promulgation and implementation of a series of policies, new energy vehicles will further promote Chinese economic and social development.

To speed up the cultivation and development of new energy vehicles, we must let the market and the government work together to accelerate the transformation and upgrading of Chinese automobile industry and enhance its international competitiveness. The so-called performance of industrial policy is the actual effect of a series of industrial policies formulated by the government on the basis of the status quo of the development of new-energy vehicles after the implementation of the new-energy automobile industry. However, there are still a series of problems that need to be solved in practice. For example, what is the effect of the implementation of the new energy automobile industry policy? Whether the intensity of industrial policy remains unchanged? Industrial policy investment process needs to adjust the weight? Whether the output index of industrial policy is satisfactory or not, etc. From the fact that industrial policy promotes industrial development, the performance of industrial policy needs to be improved and further studied.

The new energy automotive industry is an industrial cluster that produces and services products 
through the research, development and innovation of new energy vehicles. It is characterized by its strategic, intellectual-intensive, high relevance, innovation, high input, high output and environmental protection Features. Since the new century, the rapid development of the new energy automotive industry has become a new economic growth point of various countries in the world and the commanding height of the country's overall capability. To a certain extent, the development level of the new energy automobile industry determines the optimization of the industrial economic structure and the quality of economic development. It also determines the level of the country's core competitiveness and its position in the global economic pattern. All countries regard the development of new energy automotive industry as an important way to enhance their economic competitiveness, enhance their international status and speed up their economic development, so as to elevate their importance to the strategic development of the country. As a new emerging automobile industry, the new energy automobile industry needs strong support from the state to foster growth. Therefore, China has proposed a series of overall plans and policies and measures for the development of the new energy automobile industry.

\section{The State's Support Policies for New Energy Vehicles}

Since 2009, the policy of new energy automobile industry in our country has been developing rapidly under the motto of "Ten Cities, One Thousand Vehicles". It has put forward the explicit requirements on the quantity targets for promoting new energy vehicles in the early stage and has initially promoted the new energy vehicles. During the years from 2009 to 2016, Chinese new-energy automobile industry has been gradually improved. The state has enacted corresponding support for macro-market orientation, promotion and application, financial subsidies, tax incentives, infrastructure such as facilities for charging and discharging, technological innovation and industry management policy.

Under the full support of the policy, China has become the largest market for new energy vehicles in the world for seven years in a row. In 2015, for example, the cumulative sales in the whole year were 523,000 units, with 331,100 units in China being the most sold in the world. In the relevant document issued by the Ministry of Industry and Information Technology in 15 years, the investment project was determined not to be subject to the minimum threshold of the traditional automobile industry, but to determine the scale and investment amount by itself, greatly reducing the entry barrier for the new energy automobile industry. And for the battery of this nuclear technology, the policy of battery life, battery materials and other aspects have made detailed provisions, virtually mentioning the entry threshold of the battery industry is conducive to promoting the technology of power battery industry Innovation and life support. At the same time, in order to promote the convenience of new energy vehicles and to make up for the shortcomings of inconvenient charging and expensive price, the government also gave policy support in the downstream energy industry chain of new energy vehicles. Such as: new energy vehicles do not Yaohao, unlimited lines, there is no purchase policy, which on the one hand to stimulate the market played a significant role. At the same time, by monitoring the investment in $\mathrm{R} \& \mathrm{D}$ of related industries, the paper proposes the problems such as charging makeup of new energy vehicles parking lot, grading management of the promotion of new energy vehicles and unification of current chaotic charging models, standardizing the market and making new energy vehicles charge even more Convenient.

The promotion and application of NEV support policies are inseparable from the supporting role of various cities in promoting and applying cities. As of the end of May 2016, 90 effective local support policies were launched by all localities across the country. Mainly covers four aspects: local purchase subsidies, operating subsidies, charging infrastructure construction and new energy vehicles traffic management policy.

With the sales of 331,100 new energy vehicles in 2015, the policy on the promotion and application of new energy vehicles in China entered the second phase from the first phase of 2013-2015. According to the contents of the State Council meeting held on February 24, 2016, the state will continue to support the development of the new energy automotive industry. The policy 
has the following four trends: Subsidy escalation will change the double subsidy standard of "state subsidy + local subsidies" and raise the technical threshold Pratt \& Whitney policy shift to technology-specific "award-winning Fu." Local policies will be jointly with the national policy of regression, while some regions will gradually cancel the purchase of local subsidies policy; strengthen the regulatory mechanism, mainly for fraud and car safety the regulatory issues are mainly reflected in the aspects of enterprises and product access. The charging facilities are community-oriented. The government will formulate detailed policies and measures for charging makeup into the community. Greater R \& D investment will mainly promote the breakthrough development of key component technologies.

\section{The Impact Analysis of Financial Policies on the Development of New Energy Vehicles}

In our country, the new energy automobile industry policy based on the supply angle is mainly the government's direct subsidy for the research and development of new energy vehicles. Such subsidies can be traced back to the earliest "863" plan for electric vehicles launched by the state during the "Tenth Five-Year Plan" period. During the "Tenth Five-Year Plan" period, Chinese auto industry is facing an opportunity of rapid development. With economic development, Chinese automobile output and car ownership have also steadily increased. As a result, the demand for oil from automobiles has started to increase rapidly. The negative impact of automobile exhaust on the environment has also become increasingly serious. It is against this background that the "863" plan was put forward. The special proposal of "863" started the overall planning phase of Chinese new energy automobile industry. The focus of the project was mainly on electric vehicles, including three categories of pure electric vehicles, hybrid vehicles and fuel cell vehicles. The three types of electric vehicles were classified as " Three vertical ", and multi-energy control, drive motor, power battery for the" three horizontal ", the establishment of" three vertical and three horizontal "development layout. In the "863" special project for electric vehicles, the state directly invested Rmb880 million in research and development funds, providing indispensable financial support for the initial development of new energy vehicles. This is the first time that the state has paid attention to the new energy automobile industry in terms of government policies and also indicates that the government support for the new energy automotive industry in China has kicked off.

By the "Eleventh Five-Year" period, the development of Chinese new energy automotive industry ushered in the first climax. As the international oil prices continue to rise, less fuel-efficient new energy vehicles into the field of vision of some car buyers. Some auto companies are also beginning to recognize the great potential of the new energy automotive industry and have started to step up R \& D and promotion of new energy vehicles. During this period, government policies began to appear intensively to promote the rapid development of Chinese new energy automotive industry. In terms of supply policy, the government of our country directly invested nearly 2 billion RMB in research and development of new energy vehicles in 2006; in January 2009, it invested 10 billion RMB to support the industrialization of Chinese new energy vehicles and key components; the same in May of this year, another 20 billion RMB of funds was allocated to support the technological transformation of new energy vehicles and so on. After that, with the further improvement of the NEV industry, by the 12th FYP period, the state gradually reduced its funding support for new energy vehicles. The supportive focus slowly turned to consumers' needs and related supporting environment tilt.

In our country, the government policy of new energy vehicles is mainly reflected in the government's direct purchase and the purchase plan. In the "Tenth Five-Year" period, as the new energy automotive industry has just started, there is no complete product. Therefore, the national policy is not reflected in the demand side. This phenomenon lasted until the "Eleventh Five-Year" in 2008, during the 2008 Olympic Games, the government bought 500 new energy vehicles at one time to put into use. This is the first direct purchase of new energy vehicles by the government. This purchase has played an exemplary role in the promotion of new energy vehicles on the one hand, and has brought economic benefits to the enterprises producing new energy vehicles on the other hand. In February 2009, the government of our country released the policy of "demonstrating and 
popularizing the application of energy-saving and new-energy vehicles for ten cities and 1,000 hybrid buses" policy plan. In about three years, the policy plan will develop ten cities each year, each city launched a demonstration project of 1,000 new energy vehicles and confirmed that it will take the lead in 13 cities in Beijing, Shanghai, Chongqing, Changchun, Dalian, Hangzhou, Jinan, Wuhan, Shenzhen, Hefei, Changsha, Kunming and Nanchang. This shows that the Chinese government's growing emphasis on the new energy automotive industry, but also for the expansion of Chinese new energy vehicle market and let more people know and understand the new energy vehicles has made a significant contribution.

During the "11th Five-Year Plan" period, our country's environmental policy of guiding the new energy vehicles has also started to carry out the layout in all aspects. The "New Consumption Tax Policy" which was put into effect in 2006 stipulates certain tax incentives for new energy vehicles that have the characteristics of energy conservation and environmental protection in our country. Chinese new energy vehicles to provide indirect sales support. In 2009, the government directly invested in the construction of automobile battery charging stations in some demonstration cities to solve the motive force of new energy vehicles. Also in 2009, the government of our country identified 13 cities as demonstration pilot cities for new energy vehicles. On May 31, 2010, pilot cities for energy-saving and new energy vehicle demonstration were further expanded to 25 . By the end of 2010, the total number of new energy vehicles in the demonstration pilot cities exceeded 10,000 .

During the 12th Five-Year Plan period, the new energy automobile industry was listed as a strategic emerging industry. This has caused great attention to the development of new energy vehicles in various places and successively listed them as key industries. During this period, due to the accumulation of energy vehicle technologies during the "Tenth Five-Year Plan" and "Eleventh Five-Year Plan" period, Chinese new energy vehicles have entered the initial stage of large-scale market, which is also a crucial period for market cultivation and industrialization. Government policy guidance from blindly to the development of new energy vehicles has gradually become the incentive for the new energy automotive industry standardized management. On September 7, 2011, the Ministry of Finance, the National Development and Reform Commission and the Ministry of Industry and Information Technology jointly issued the Notice on Adjusting the Policy of Subsidy for Promoting Energy-saving Vehicles (hereinafter referred to as the "Notice"), and the Notice states that by 2011 On September 30, 2008, the purchase subsidies for the new NEVs in China are completed. The new subsidy policy for new energy vehicles has been officially implemented since October 1, 2011. Compared with the old subsidy policy, the threshold of new energy vehicles that are included in the scope of subsidies has been significantly raised. Fuel consumption has risen from an average of 6.9 liters per 100 kilometers to an average of 6.3 liters per 100 kilometers. The subsidy standard has not changed. Consumers who purchase new energy vehicles give a one-time quota subsidy of 3,000 RMB and are redeemed by consumers of new-energy vehicles at the time of sales. Subsidy "threshold children" increase the purpose is to further promote the new energy vehicles in the future to promote the core technology and product structure optimization and upgrading, continue to guide consumers to buy new energy vehicles. As can be seen from the latest standards, most of the new-energy automobile models that meet the latest standards adopt new engine technology and transmission technology.

\section{Conclusions}

At present, great progress has been made in popularizing and applying new energy vehicles. However, there are still some problems that are urgently solved, such as the lack of technology in enterprises, lack of technology, and the bottleneck of basic charging design in residential areas. In order to win the subsidies for the dual supportive policies of the state and local governments, some provincial and municipal enterprises and units quickly put together products that fail to meet the quality and safety standards. In the parts, interests oriented and ignore the performance and quality, all purchases of local products. As one of Chinese major strategic emerging industries, the new energy automotive industry needs to suggest a comprehensive, multi-angle and complete policy 
system of industrial clusters and national standards.

\section{References}

[1] Liao Jiaqin, Sun Xiaocheng. Study on the effect of fiscal policy on new energy vehicles [J]. Taxation and Economy. 2017 (01)

[2] Fan Huixia. The Conflicts of Industrial Policy Effectiveness and Choice of Tax Policy [J]. Revenue Research. 2016 (12)

[3] Tan Xiaofen, Yin No strings, Dai. Effects of US QE on the emerging economies [J]. International Finance Research. 2016 (07)

[4] Wu Yan, He Zheng-chu. Industrial Convergence of New Energy Vehicles and Manufacturing Services and Its Influencing Factors [J]. Systems Engineering. 2016 (06)

[5] Wang Qian, Ma Yunxiao. Corporate Governance Effect of Shanghai-Hong Kong Stock Connect Policy - An Empirical Analysis Based on Incident Research [J]. Financial Forum 2016 (05)

[6] Zhang Zhongyun, Li Chunli. Japan's new energy vehicles related policies and future development path selection [J]. Modern Japanese Economy. 2015 (05) 